\title{
SOME EFFECTS OF INJECTING STERILE SOLUTIONS OF STREPTOKINASE-STREPTODORNASE INTO THE SUB- ARACHNOID SPACE OF NORMAL RHESUS MONKEYS ${ }^{1,2}$
}

\author{
BY MORTON HAMBURGER AND J. PARK BIEHL \\ (From the Department of Internal Medicine, University of Cincinnati College of Medicine, and \\ the Cincinnati General Hospital, Cincinnati, O.)
}

(Submitted for publication December 1, 1952; accepted January 8, 1953)

Streptokinase (SK) and streptodornase (SD) solutions have been injected into the subarachnoid space of patients with meningitis, in order to promote the resolution of the inflammatory exudate $(1-6)$. Because side reactions have been reported in certain cases $(2,3)$, it seemed desirable to ascertain the effect of injecting the enzymes into the uninfected subarachnoid space. Such a study was

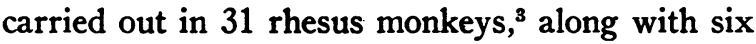
others in which sterile saline was substituted for the enzyme. It is the purpose of this paper to report the results of the study.

\section{METHODS}

The animals were anesthetized with pentobarbital. A cisternal tap was performed, and 2 to 3 cc. of spinal fluid removed. The enzymes were dissolved in $1 \mathrm{cc}$. of sterile saline, prepared from triply distilled water, and injected into the cisterna magna a few minutes later. Twentyfour hours afterwards, a second cisternal tap was performed. Total white and red blood cell counts, differential counts, and Pandy test were done on each sample of spinal fluid, and in some instances cultures were made. Some of the animals were then sacrificed, but others were permitted to live and were retapped at frequent intervals.

Three separate lots of enzyme solution were employed, all supplied by the Lederle Laboratories. The following concentrations were investigated: Lot 23-A : 2000 units SK plus 750 units SD; Lot 23-A : 20,000 units SK plus 7500 units SD; Lot 25-A : 2000 units SK plus 666 units SD; Lot 27-A : 2000 units SK plus 10,000 units SD.

1 This work was done under the sponsorship of the Commission on Streptococcal Diseases, Armed Forces Epidemiological Board.

2 Streptokinase-streptodornase was generously supplied by the Lederle Laboratories, through the courtesy of Dr. James M. Ruegsegger and Dr. Stanton M. Hardy.

${ }^{8}$ Monkeys used in this study were generously supplied by Dr. L. H. Schmidt, Director of the Institute for Medical Research, Christ Hospital, Cincinnati, Ohio. These monkeys had been previously used in an investigation of malaria chemotherapy. They had all been splenectomized but were otherwise entirely normal.

\section{RESULTS}

The cerebrospinal fluid response 24 hours after injection of enzyme solutions. In every instance the spinal fluid became turbid and a vigorous pleocytosis was observed. The spinal fluid counts in 87 per cent of 23 monkeys varied between 1100 and 4000, with three counts between 14,000 and 15,100 . In most instances polymorphonuclear leucocytes predominated. The Pandy reaction became strongly positive.

TABLE I

Spinal fluid leucocyte count 24 hours after injection of streptokinase-streptodornase solutions into subarachnoid space of uninfected monkeys

\begin{tabular}{|c|c|c|c|c|}
\hline & \multicolumn{3}{|c|}{ Dose of Enzyme (Christensen Units) } & \multirow{2}{*}{$\begin{array}{l}\text { Sterile } \\
0.9 \% \\
\mathrm{NaCl}\end{array}$} \\
\hline & $\begin{array}{r}2000 \mathrm{SK} \\
750 \mathrm{SD}\end{array}$ & $\begin{array}{r}20,000 \mathrm{SK} \\
7,500 \mathrm{SD}\end{array}$ & $\begin{array}{r}2,000 \text { SK } \\
10,000 \text { SD }\end{array}$ & \\
\hline $\begin{array}{l}\text { Median W.B.C. } \\
\text { Count }\end{array}$ & 1790 & 4700 & 4000 & 314 \\
\hline Range & $1100-4000^{*}$ & $1400-14,150$ & $3750-14,200$ & 44-1926 \\
\hline $\begin{array}{l}\text { Number of } \\
\text { monkeys }\end{array}$ & 10 & 8 & 5 & 6 \\
\hline
\end{tabular}

SK = Streptokinase.

$\mathrm{SD}=$ Streptodornase.

$*=1$ count was 15,100 .

The effect of varying the enzyme concentration is shown in Table I. Two thousand units of streptokinase and 750 units of streptodornase in the same solution produced a median white count of 1790 per cu. $\mathrm{mm}$. at the end of 24 hours. Higher concentrations of either enzyme increased the pleocytosis somewhat. Thus 20,000 units of SK and 7500 units SD gave a median count of 4700 . When a solution was used which contained 2000 units of streptokinase but 10,000 of streptodornase the count was 4000 . Inasmuch as the solutions were prepared in physiological saline, six monkeys were injected with 1 cubic centimeter of 0.9 per cent sodium chloride. Their median cerebrospinal fluid white cell count at the end of 24 hours was 314 . 


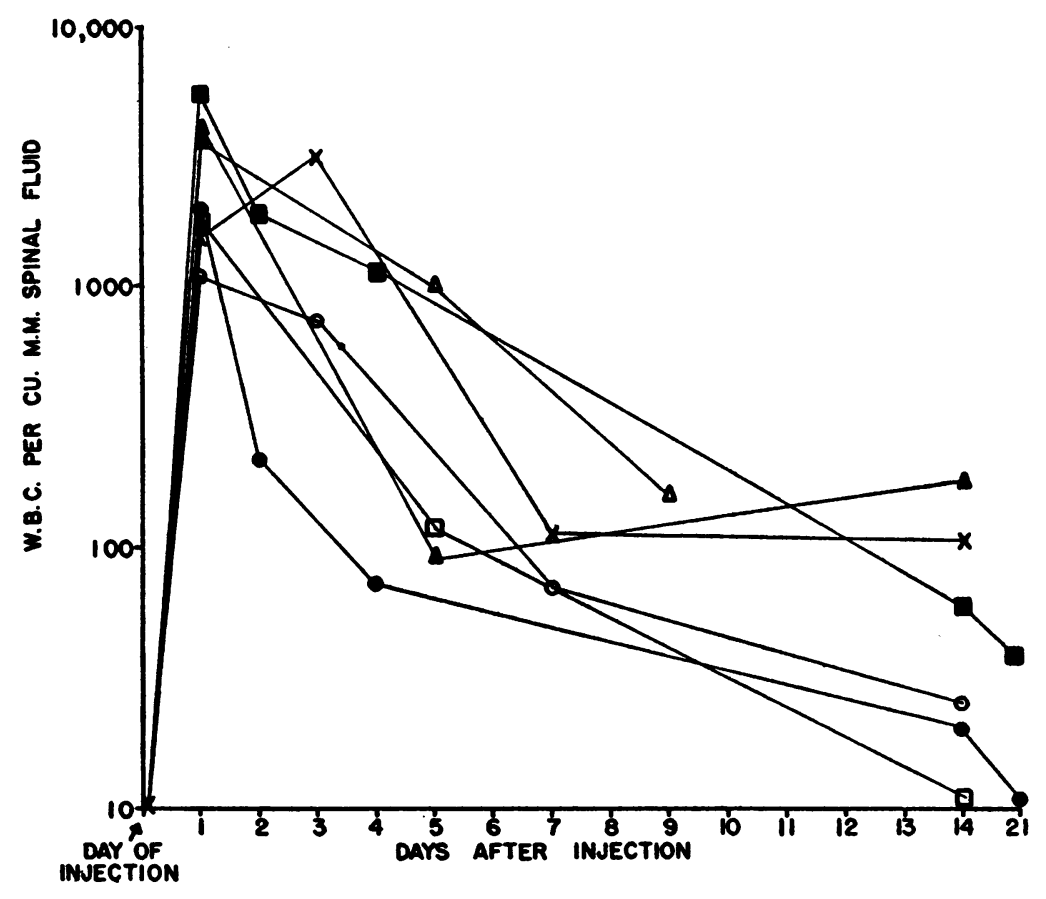

Fig. 1. Spinal Fluid White Crul Counts Following Injection of Sterile Streptokinase-Streptodornase into Cisterna Magna of Rhesus MONKEYS

These counts had fallen to normal within three to nine days. Thirty-six specimens of spinal fluid and surfaces of nine brains were cultured. All were sterile.

Despite these striking changes in the cerebrospinal fluid, the monkeys were not at all ill. After they recovered from the pentobarbital anesthesia, they appeared normal and alert. They ate well and exhibited no obvious neurological abnormality.

Fourteen monkeys, including representatives from each dosage schedule, were sacrificed 24 or 48 hours after injection of streptokinase-streptodornase solution. In only two animals was any gross exudate present, and in these it was minimal in extent. Most of the brains displayed slight degrees of injection of the blood vessels. Microscopic sections showed, in the majority of instances, slight degrees of polymorphonuclear reaction in the meninges. The underlying brain was never involved.

Duration of pleocytosis. Follow-up cisternal taps were performed at various intervals in six monkeys. The results (Figure 1) show that the spinal fluid white count dropped sharply from the initial level within two to four days in five of the six monkeys. By the end of a week they were all below 200 per cu. $\mathrm{mm}$. By the end of two weeks they had dropped to nearly normal.

Effect of two injections on successive days. Two successive injections of 2000 units SK and 750 SD were given, 24 hours apart, to each of three monkeys. Twenty-four hours after the first injection the average spinal fluid white cell count was 2850 per cu. $\mathrm{mm}$. The second injection did not increase the pleocytosis, the average count 24 hours later being 2988.

Effect of inactivated $S K-S D$. An enzyme solution containing 2000 units SK and 750 units SD was inactivated by heating at $56^{\circ} \mathrm{C}$ for 48 hours, and then injected into the subarachnoid space of five monkeys. A solution heated at $56^{\circ} \mathrm{C}$ for 24 hours was used in three other animals. The median spinal fluid leucocyte count was 3400 per cu. $\mathrm{mm}$. with extremes of 1670 and 4750 . No exudate was seen on the brain of any of the first five monkeys following sacrifice. The other three were permitted to live.

\section{DISCUSSION}

It is clear from these experiments that the injection of sterile SK-SD solutions into the unin- 
fected subarachnoid space incites a vigorous outpouring of leucocytes and protein without the concomitant laying down of gross exudate in the meninges. Inasmuch as the effect was produced by inactivated as well as active enzyme, it seems likely that the spinal fluid changes were due to a non-specific protein effect. As far as we can ascertain, no reports have so far appeared in which the effect of injecting these enzymes into normal body cavities has been described.

However, Johnson (7) found that the injection of active enzyme into the pleural cavity of two patients with non-suppurative effusion led to an increase in cell count, whereas the injection of inactivated enzyme failed to do so.

\section{SUMMARY}

The injection of sterile solutions of streptokinase and streptodornase into the subarachnoid space of normal rhesus monkeys invoked a vigorous polymorphonuclear pleocytosis and a positive Pandy reaction. The white counts dropped sharply within a few days and were practically normal within two weeks. These effects were not accompanied by any sign of clinical illness in the monkeys nor by the laying down of gross exudate upon the brains of animals which were sacrificed.

\section{ACKNOWLEDGMENTS}

We are grateful to Miss Judith Carleton and Mrs. Jean Donnelly for excellent technical assistance.

\section{REFERENCES}

1. Cathie, I. A. B., Streptomycin-streptokinase treatment of tuberculous meningitis. Lancet, 1949, 1, 441.

2. Cathie, I. A. B., and MacFarlane, J. C. W., Adjuvants to streptomycin in treating tuberculous meningitis in children. Lancet, 1950, 2, 784.

3. Lorber, J., Streptokinase as an adjunct in the treatment of tuberculous meningitis. Lancet, 1951, 1, 1334.

4. Tillett, W. S., Studies on the enzymatic lysis of fibrin and inflammatory exudates by products of hemolytic streptococci. The Harvey Lectures, 1949-50, Series XLV, p. 149.

5. Craddock, W. L., and Haddock-Suarez, J., Terminal hyperthermia following intrathecal streptokinase administration in a case of tuberculous meningitis. Ann. Int. Med., 1952, 36, 168.

6. Knight, V., Hardy, R. C., and Negrin, J., Jr., Meningitis due to pseudomonas aeruginosa. Intrathecal treatment with streptokinase and streptodornase with intramuscular and intrathecal treatment with neomycin. J.A.M.A., 1952, 149, 1395.

7. Johnson, A. J., Cytological studies in association with local injections of streptokinase-streptodornase into patients. J. Clin. Invest., 1950, 29, 1376.

\section{SPECIAL NOTICE TO SUBSCRIBERS}

Post Offices will no longer forward the Journal when you move.

Please notify The Journal of Clinical Investigation, Business Office, 622 West 168th Street, New York 32, N. Y. at once when you have a change of address, and do not omit the zone number if there is one. 